Vol. 4 No. 3 September 2017

(Erina Permatasari)

\title{
PERAN DAN TANGGUNG JAWAB NOTARIS \\ TERHADAP PELAKSANAAN PENDAFTARAN BADAN HUKUM PERSEROAN TERBATAS MELALUI SISTEM ONLINE
}

\author{
Erina Permatasari', Lathifah Hanim ${ }^{* *}$ \\ * Mahasiswa Program Magister (S2) Kenotariatan Fakultas Hukum UNISSULA email: erinapermata94@yahoo.com \\ ${ }^{* *}$ Dosen Fakultas Hukum UNISSULA
}

\begin{abstract}
The aims of this research were to looking for and analyzing: 1) Company registration procedure by online sysem, 2) Notary's role and responsibility in the company registration by online system, if had error inputing data, 3) the law effect of notary's role and responsibility if had been error inputing data, from UU ITE sight and 1365 KUHPerdata chapter sight. Data using was primary data, secoundary and tersier as supporting data, and then analized by quantitative-descriptive methode.

Based on nalizing result had some conclusion that: 1) Registratin company procedure by online system that in generally beginning from company name order and been follow up with making the companies act as the SABH forms in electronics by notary. If the data input was complete and right also had been agree by Law and human Right Ministery so been had Decission Letter of law entity legalacyby Minister. 2) Role of the notary in company registration with online system was since client ask to registration the company until Decission Letter of law entity legalacyby Minister was out. The notary responsibility if done guilty like error inputing data, no related with UU ITE because no chapter about, but with 1365 BW chapter where doing of error inputing data was harming another person so hane to re the harmed with repairing the data and make act changing.

Keywords: Notary, Company Resgistration, Online
\end{abstract}

\section{PENDAHULUAN}

Notaris merupakan pejabat umum yang memiliki kewenangan membuat akta-akta terkait tindakan, perjanjian dan keputusan-keputusan yang oleh perundang-undangan umum diwajibkan atau para yang bersangkutan supaya dinyatakan dalam surat yang bersifat otentik, menentukan tanggalnya, menyimpan aktanya dan memberikan grosse (salinan sah), salinan dan kutipannya, dan semuanya itu selama pembuatan akta-akta itu tidak juga diwajibkan kepada pejabat atau khusus menjadi kewajibannya. ${ }^{1}$

Dalam kaitannya dengan pembuktian kepastian hukum termasuk di dalamnya adalah hak serta kewajiban seseorang membutuhkan peran notaris. Peran Notaris terkait bantuan

1 Pasal 1 Undang-Undang Nomor 2 Tahun 2014 Tentang Jabatan Notaris.. memberi kepastian hukumnya dan perlindungan hukumnya bagi masyarakat sangatlah penting. Peran notaris ini lebih bersifat pencegahan atau preventif akan terjadinya masalah hukum di masa datang dengan membuat akta otentik terkait dengan status hukum, hak dan kewajiban seseorang dalam hukum, dan lain sebagainya yang berfungsi sebagai alat bukti yang paling sempurna di pengadilan yaitu dalam hal terjadi sengketa hak dan kewajibannya itu. ${ }^{2}$

Notaris dalam melakukan tugasnya didasari oleh peraturan perundang-undangan yang sering disebut Undang-Undang Jabatan Notaris (UUJN) Nomor 2 Tahun 2014 Jo. UU Nomor 30 Tahun 2004. Dalam ketentuan Peraturan Jabatan Notaris maupun Undang-undang Jabatan Notaris (UUJN)

\footnotetext{
${ }^{2}$ Sjaifurahman \& Habi Adjie. 2011. Aspek Pertanggungjawaban Notaris dalam Pembuatan Akta. Bandung. CV. Mandar Maju. HIm. 7-8. .
} 
tersebut pada intinya menyatakan bahwa tugas utama seorang notaris adalah membuat akta-akta otentik. Dalam Pasal 1870 KUHPerdata dikatakan bahwa akta otentik memberi perjanjian yang absolut kepada para pihak yang membuatnya. Dengan demikian maka pentingnya jabatan notaris adalah pada kewenangan notaris yang diberikan oleh undang-undang untuk membuat perangkat atau alat pembuktian yang absolut dan karenanya akta otentik tersebut pada hakikatnya dinilai benar. Sehingga merupakan hal yang sangat penting khsusnya pihak yang membutuhkan dalam urusan pribadi atau usaha.

Akta Notaris berperan penting dalam menciptakan kepastian hukum karena sifat otentiknya dan dapat digunakan sebagai alat pembuktian yang kuat dan penuh bila terjadi masalah yang berhubungan dengan akta tersebut. Dewasa ini kebutuhan terhadap akta otentik sebagai pembuktian semakin meningkat seiring dengan meningkatkanya hubungan bisnis di berbagai bidang usaha baik dari skala lokal hingga internasional. $^{3}$

Dari sekian banyaknya kebutuhan akan akta otentik dalam bidang bisnis, salah satunya adalah akta Perseroan Terbatas. Akhir-akhir ini Perseroan Terbatas merupakan bentuk usaha yang paling diminati dan paling disukai oleh masyarakat yang berkecimpung di dunia usaha atau bisnis karena pertanggungjawabannya yang bersifat terbatas. Pasal 1 ayat (1) Undang-undang Nomor 40 tahun 2007 memberi pengertian perseroan terbatas sebagai suatu badan hukum perkumpulan modal berdasar perjanjian untuk berusaha dengan modal dasar dalam bentuk saham sesuai ketetapan undang-undang terkait. ${ }^{4}$

Berdasarkan UUPT Nomor 40 tahun 2007 dalam Pasal 7 ditetapkan bahwa perseroan didirikan oleh dua (2) orang atau lebih dengan akta notaris yang dibuat dalam bahasa Indonesia. Dalam pembuatan Akta Pendirian, Pendiri dapat diwakili oleh orang lain misalnya oleh Notaris, berdasarkan surat kuasa. Proses pendaftaran Perseroan Terbatas di dalam Keputusan Menteri Kehakiman dan Hak Asasi Manusia Nomor M-04

\footnotetext{
${ }^{3}$ Sjaifurahman \& Habi Adjie. Ibid. HIm. 8.

${ }^{4}$ Seperti yang tertera pada Pasal 1 UU Nomor 40 tahun 2007 tentang Perseroan Terbatas.
}

HT.01.01 Tahun 2001 adalah dilakukan secara manual. Seiring dengan perkembangan jaman yang membutuhkan kecepatan dalam memproses suatu administrasi dan seiring dengan perkembangan teknologi saatt ini, maka cara manual dinilai sudah tidak efisien dan efektif karena prosesnya lama karena prosesnya yang lama hingga berbulan-bulan. Berdasarkan alasan tersebut maka Pemerintah menerbitkan ketentuan baru berupa Keputusan Menteri Kehakiman dan Hak Asasi Manusia Nomor M-05 HT.01.01 Tahun 2002 tentang Pemberlakuan Sistem Administrasi Badan Hukum di Direktorat Jenderal Administrasi Hukum Umum Departemen Kehakiman dan Hak Asasi Manusi Republik Indonesia, di mana di dalamnya disebutkan bahwa proses penyelesaian badan hukum yang meliputi badan hukum yang di dalamnya meliputi permohonan pengesahan akta pendirian Perseroan Terbatas dan permohonan persetujuan serta penyampaian laporan akta perubahan anggaran dasar Perseroan Terbatas, dilaksanakan dengan Sistem Administrasi Badan Hukum (SISMINBAKUM) secara online. Dan sistem lama yaitu sistem manual berakhir sejak tanggal 30 Juni 2002.

Peraturan baru yang dikeluarkan berupa Peraturan Menteri Hukum dan Hak Asasi Manusia (PERMENKUMHAM) Republik Indonesia Nomor 4 Tahun 2014 tentang Tata Cara Pengajuan Permohonan Pengesahan Badan Hukum dan Persetujuan Anggaran Dasar serta Penyampaian Pemberitahuan Perubahan Anggaran Dasar dan Perubahan Data Perseroan Terbatas yang diperbaharui dengan Permenkumham Nomor 1 tahun 2016 tentang Perubahan Atas Peraturan Menteri Hukum dan Hak Asasi Manusia Nomor 4 tahun 2014 tentang Tata Cara Pengajuan Permohonan Pengesahan Badan Hukum dan Persetujuan Anggaran Dasar serta Penyampaian Pemberitahuan Perubahan Anggaran Dasar dan Perubahan Data Perseroan Terbatas yang dilakukan melalui media elektronik (Online).

Perubahan dari sistem manual ke siditem elektronik atau secara online diharapkan agar dalam pendaftaran atau pengesahan tersebut dapat berjalan lebih efisien dan lebih efektis. Tidak berbeda dengan ketentuan sebelumnya, dalam ketentuan yang baru ini di dalam pelaksanaannya 
tettap membutuhkan peran notaris. Di dalam pelaksanaan $\mathrm{SABH}$ online tidaklah tertutup kemungkinan adanya suatu permasalahan yang dapat menjadi kendala khususnya terkait dengan peran dari notaris. Kendala-kendala yang dapat terjadi antara lain adalah kurangnya pengetahuan dan pemahaman tentang $\mathrm{SABH}$, kurang terampil dalam mengoperasikan komputer maupun internet sebagai sarana utama dalam $\mathrm{SABH}$ secara online, dan kekurangan-kekurangan lainnya. Dalam hal keadaan demikian maka notaris memiliki wewenang untuk melimpahkan tugas pengadministrasian tersebut kepada orang lain pekerjaan yaitu karyawannya. Hal-hal seperti demikian sangat memungkinkan terjadinya kesalahan pemasukan data atau keabsahan data bahkan dapat juga terjadi penyalahgunaan data. Apabila hal ini terjadi maka akibat yang timbul di dalamnya adalah menjadi tanggung jawab dari Noaris itu sendiri.

\section{METODE PENELITIAN}

Penelitian ini menggunakan metode Yuridis Normatif untuk menemukan kebenaran dengan logika ilmu hukum normatif. Keajegan keilmuan dalam hukum normatif didasari disiplin ilmiah dengan ilmu hukum sebagai objeknya. ${ }^{5}$ Spesifikasi dalam penulisan ini yaitu Deskriptif Analitis yaitu penulisan yang menggambarkan kenyataan tentang kebudayaan suatu masyarakat secara fenomenologis dan apa adanya dalam konteks satu kesatuan yang integral.

Berdasarkan jenis serta asal data maka pengumpulan data penelitian ini yakni Data primer, dilakukan dengan menginventarisasi bahan hukum primer seperti peraturan perundang-undangan, yurisprudensi, dan doktrin yang relevan dengan penelitian ini. Data sekunder dilakukan dengan cara mengumpulkan dan memeriksa atau menelusuri dokumen atau kepustakaan yang dapat memberikan informasi atau keterangan yang dibutuhkan oleh peneliti seperti hasil-hasil penelitian atau jurnal ilmiah, literatur, makalah dalam seminar, dan artikel ilmiah lainnya.

\footnotetext{
${ }^{5}$ Johny Ibrahim, Teori dan Metode Penelitian Hukum Normatif, Malang; Banyu Media, 2008, hlm 57.
}

\section{HASIL PENELITIAN DAN PEMBAHASAN}

\section{Prosedur Pendaftaran Perseroan Terbatas Melalui Sistem Online}

Seiring dengan perkembangan jaman globalisasi pemanfaatan teknologi modern terjadi pada semua aspek kehidupan tidak terkecuali penggunaan jaringan internet dalam dunia bisnis. Bahkan dalam dunia hukum, jaringan internet juga diaplikasikan untuk mempermudah layanan pendaftaran suatu badan hukum/perusahaan seperti Perseroan Terbatas dalam sistem administrasinya.

Mekanisme pendaftaran dan pengesahan Perseroan Terbatas secara online berdasarkan hasil wawancara dengan notaris adalah diawali dengan pemesanan nama Perseroan Terbatas secara online. ${ }^{6}$ Dalam pemesanan nama tersebut PT selaku pemohon terlebih masuk ke halaman muka situs www.ahu.go.id ke bagian SIMPADHU untuk melakukan pemesananan voucher pemesanan nama perseroan dijelaskan pula bahwa batas pembayaran hanya 2 hari dari tanggal pemesanan voucher apabila telah lewat dari 2 hari maka nomor voucher tidak dapat digunakan. Setelah itu Pemohon kembali ke situs www.ahu.go.id ke PERSEROAN TERBATAS dan muncul tampilan PERSEROAN. Setelah itu melakukan pemesanan nama dan memasukkan kode vocher yang telah dibayar dan nama perusahaan yang diinginkan. Setelah itu akan muncul tampilan pernyataan bahwa nama yang dipesan sesuai dengan ketentuan peraturan perundang-undangan, kemudian keluar menu diterima atau atau tidak diterima pemesanan namanya dan bila ada nama yang sama maka harus diganti.

Berdasarkan pengalaman dari beberapa notaris tentang pendaftaran perseroan terbatas dengan sistem online yang pada intinya sama, dapat dikatakan bahwa pendaftaran perseroan terbatas sistem online terbukti praktis, yang dinilai dari beberapa hal berikut, yaitu:

\footnotetext{
${ }^{6}$ Hasil wawancara dengan Notaris SS (Semarang), Notaris NH (Cilacap), dan Notaris ZA (Semarang), Juli 2017.
} 
1. Pendaftaran dengan sistem online lebih praktis karena tidak perlu membawa banyak berkas/file jauh-jauh ke Jakarta dengan resiko hilang atau berkasnya ada yang ketinggalan sehingga harus bolak-balik ke Jakarta. Efisien, karena

2. Hemat waktu, karena waktu yang dibutuhkan dari pendaftaran sampai mendapatkan SK hanya satu bulan, sedangakan dengan cara manual membutuhkan waktu lama hingga 6 bulan.

3. Tidak perlu jaun-jauh ke Kantor Kemenkuham untuk melakukan pendaftara perseoran terbatas, cukup dilakukan di kantor sendiri sehingga hemat biaya, waktu dan tenaga.

4. Transparant, dengan sistem online pendaftaran dilakukan secara terbuka tidak ada yang disembunyikan karena bila ada kesalahan resiko ditanggung oleh notaris sendiri.

5. Meminimalisir atau menghilangkan praktek kolusi yang pada dasarnya adalah perbuatan atau tindakan yang bertentangan dengan hukum itu sendiri.

Jadi dapat dikatakan bahwa pendaftaran perseroan terbatas menggunakan sistem online tidak hanya praktis tapi juga lebih cepat, efisien, efektif, ekonomis, transparan dan dapat meminimalisir atau menghindarkan terjadinya perbuatan atau tindakan yang melanggar atau bertentangan dengan hukum seperti melakukan kolusi atau pungutan liar.

\section{Peran dan Tanggung Jawab Notaris dalam Pendaftaran Perseroan Terbatas Melalui Sistem Online}

\section{Peran Notaris dalam Pendaftaran} Perseoran Terbatas Melalui Sistem Online

Peran notaris dalam pendaftaran perseroan terbatas secara online adalah sebagaimana yang disampaikan oleh para informan adalah memasukkan data perseroan terbatas, melakukan pengecekan terhadap semua data yang sudah dimasukkan untuk menghindari kesalahan pemasukan data, kemudian baru ditandatangani. ${ }^{7}$ Berdasar hasil wawancara dengan responden, diperoleh pendapat yang berbeda tentang peran notaris,

\footnotetext{
${ }^{7}$ Hasil wawancara dengan Notaris SS Semarang, Notaris NH Cilacap, dan Notaris ZA Semarang, Juli 2017.
}

namun sangat jelas ditemukan benang merahnya yaitu bahwa peran notaris dalam pendaftaran perseroan terbatas adalah sebatas pemeriksaan data akta pemohon dan membacakan akta yang sudah dibuat sebelum ditandatangani notaris. Dari hasil penelitian tersebut diperoleh fakta bahwa notaris menganggap tindakan yang dilakukan olehnya dalam rangkaian proses pendaftaran perseroan terbatas dari pemesanan nama perseroan hingga terbitnya SK akta dari Kemenkuham bukanlah perannya, padahal jelas-jelas kegiatan tersebut merupakan tindakan peran notaris sebagai pejabat yang berwenang mengesahkan badan hukum, walaupun pada prakteknya dibantu oleh asisten atau pegawai administrasi di kantornya tetapi berada di bawah perintah notaris sehingga hal tersebut masih dalam lingkup peran notaris. Tindakan pengecekan data dengan cermat dan teliti merupakan sebagian peran, dari serangkaian peran notaris dalam pendaftaran perseroan terbatas secara online.

Kesalahan data pada saat proses memasukkan data ke sistem merupakan hal yang tidak diinginkan oleh siapapun, namun kadang hal tersebut tetap terjadi. Keadaan tersebut tentunya tidak lepas dari peran notaris. Menurut para informan, bila terjadi kesalahan pemasukan data peran notaris adalah mengoreksi data sebelum diinput atau diupload $^{8}$, dan notaris mengecek bagian yang salah dan dicocokan dengan data yang dibawa oleh pemohon sebab apabila terjadi kesalahan dari pihak notaris maka notaris harus bertanggung jawab dengan membuatkan akta baru dengan biaya dari notaris, namun bila kesalahan dari pihak pemohon maka notaris akan menyampaikan yang semestinya harus membuat akta baru dengan biaya client sendiri. ${ }^{9}$

\section{Tanggung Jawab Notaris dalam Pendaftaran Perseroan Terbatas Melalui Sistem Online}

\footnotetext{
${ }^{8}$ Hasil wawancara dengan Notaris NH Cilacap dan Notaris SS Semarang, Juli 2017.

${ }^{9}$ Hasil wawancara dengan Notaris ZA Semarang, Juli 2017.
} 
Dalam pendirian Perseroan Terbatas, tanggung jawab notaris dimulai pada saat pembuatan akta pendirian Perseroan Terbatas dihadapan notaris yang memuat di antaranya tentang perumusan maksud dan tujuan perseroan, karena itu notaris dituntut untuk seteliti mungkin mengenai hal-hal yang termuat dalam Akta Pendirian tersebut.

Hasil wawancara dengan informan tentang tanggung jawab notaris dalam pendaftaran dengan sistem online adalah jika kesalahan ada di pihak kantor notaris maka notaris akan memperbaiki dengan biaya dari notaris. Namun tetap ada kerjasama dengan pemohon, misal dalam proses perbaikan/perubahan membutuhkan data-data RUPS dan undangan rapat, maka dibuatkan oleh notaris dan pemohon yang tandatangan. ${ }^{10}$ Sementara informan lainnya menyatakan bahwa jika notaris yang salah maka menjadi tanggungjawab motaris sepenuhnya, dan notaris memperbaiki akta yang salah dengan biaya notaris sendiri. ${ }^{11}$

3. Akibat Hukum Terhadap Peran dan Tanggung jawab Notaris Apabila terjadi Kesalahan Pemasukan Data

Notaris yang membuat akta tidak sesuai dengan ketentuan peraturan perundangundangan yang berlaku maka dapat dijatuhi sanksi yang tegas oleh Majelis Pengawas Notaris sehingga di masa yang akan datang dapat diminalisir pembuatan akta notaris yang tidak sesuai dengan ketentuan peraturan perundang-undangan di bidang hukum kenotariatan.

Menurut hasil wawancara akibat hukum adanya kesalahan pemasukan data yang berlaku pada peran dan tanggung jawab notaris adalah akta tersebut tetap berlaku, namun disertai dengan akta perubahan yang dibuat oleh notaris disertai dengan data yang baru yang dikirim kembali ke Kemenkuham dengan sistem online, yang akan disusul dengan

\footnotetext{
2017.

${ }^{11}$ Hasil Wawancara dengan Notaris NH Cilacap, dan Notaris ZA Semarang, Juli 2017.
}

${ }^{10}$ Hasil Wawancara dengan Notaris SS Semarang, Juli terbitnya SK baru. ${ }^{12}$ Hal tersebut juga ditegaskan oleh informan lainnya dengan menyatakan bahwa jika ada kesalahan berakibat adanya resiko yang harus ditanggung oleh notaris ${ }^{13}$, dan informan lain yang menyatakan bahwa akibat hukumnya adalah akta tersebut dikoreksi dan harus diulangi dan diperbaiki lagi, namun nomor aktanya tetap sama. ${ }^{14}$

\section{PENUTUP}

\section{Kesimpulan}

1. Prosedur Pendaftaran PT melalui sistem online secara umum, pada pendirian PT melalui mekanisme SABH dimulai dengan dilakukannya permohonan pemesanan nama perseroan dan ditindaklanjuti dengan pembuatan akta pendirian PT. Notaris melakukan pengisian data PT dan menyampaikan kepada Kementerian Hukum dan HAM sesuai dengan format SABH secara elektronik. Apabila pengisian data lengkap dan benar, maka seketika itu juga akan dikeluarkan Surat Pernyataan Elektronik tentang Kebenaran Data Perseroan Terbatas, kemudian bila disetujui oleh Menteri secara online dilanjutkan penerbitan SK pengesahan badan hukum oleh Menteri untuk selanjutnya dicetak sendiri oleh pemohon. Pendaftaran perseroan terbatas secara online lebih praktis, lebih mudah, lebih cepat, lebih efisien dan efektif serta transparan sehingga dapat meminimalisir terjadinya kolusi.

2. Peran dan Tanggungjawab notaris dalam pelaksanaan pendaftaran Perseroan Terbatas secara online adalah :

- Penginputan data untuk pesan nama PT

- Membuatkan Akta

- Menginformasikan NPWP dan mengintruksikan keterangan domisili

- Membayar PNBN

\footnotetext{
${ }^{12}$ Hasil Wawancara dengan Notaris SS Semarang, Juli 2017.

${ }^{13}$ Hasil Wawancara dengan Notaris NH Cilacap, Juli 2017. 2017.
} 
- Menginput data untuk dijadikan SK Mentri tentang pengesahan Badan Hukum Perseroan Terbatas.

3. Akibat Hukum terhadap Peran dan Tanggungjawab Notaris apabila terjadi kesalahan pemasukan data, tidak terkait dengan UU ITE karena tidak ada pasalnya yang menyebutkan secara eksplisit ataupu implisit bahwa notaris dapat dikenai sanksi apabila melakukan kesalahan pemasukan data dalam pendaftaran perseroan terbatas dengan sistem online. Namun terkait dengan Pasal 1365 KUHPerdata Notaris di mana tindakan kesalahan pemasukan data dapat merugikan pihak lain sehingga harus mengganti kerugian dengan memperbaiki data dan membuat akta perubahan dengan biaya dibebankan kepada notaris yang melakukan kesalahan.

\section{Saran}

1. Bagi Kementerian Hukum dan Hak Azasi Manusia khususnya Direktorat Jenderal Administrasi Hukum Umum (AHU) agar dapat melakukan peningkatan dalam pelayanan $\mathrm{SABH}$, seperti menyederhanakan prosedur serta persyaratan kelengkapan dalam pengesahan badan hukum Perseroan Terbatas. Dan lebih di mudahkan dalam pengajuan pengkoreksian data perseroan yang telah terlanjur di sahkan Menteri Hukum dan Hak Azasi Manusia. Dan juga dalam hal peningkatan penyebaran jaringan internet merata di semua daerah di Indonesia untuk membantu Notaris memudahkan proses pelaksanaan SABH secara online. Pengamanan SABH menggunakan jaringan internet lebih dijaga dan ditingkatkan agar hacker tidak bisa menerobos sistem.

2. Bagi Notaris agar dapat lebih cermat, teliti, dan melakukan pemeriksaan ulang saat pendaftaran perseroan terbatas dengan sistem online agar tidak terjadi kesalahan pemasukan data yang dapat merugikan pemohon dan notaris sendiri.

\section{DAFTAR PUSTAKA}

\section{A. Buku-buku}

Johny Ibrahim, Teori dan Metode Penelitian Hukum Normatif, Malang: Banyu Media, 2008.

Sjaifurrachman dan Habib Adjie, Aspek Pertanggungjawaban Notaris dalam Pembuatan Akta, Bandung: CV. Mandar Maju,

\section{B. Perundang-undangan}

Undang-Undang Nomor 2 Tahun 2014 Tentang Jabatan Notaris

Undang-Undang Nomor 40 Tahun 2007 Tentang Perseoran Terbatas 